https://doi.org/10.48009/1_iis_2009_146-149

\title{
ADDING AUDIO AND VIDEO TO A MICROCOMPUTER APPLICATIONS CLASS TO IMPROVE STUDENT LEARNING
}

\author{
Sylvia A. Bembry, Winston-Salem State University, bembrys@wssu.edu \\ Carolyn L. Anderson, Winston-Salem State University, andersonc@ wssu.edu
}

\begin{abstract}
This article discusses audio and video use in a microcomputer applications course to improve student learning. In the past, the traditional lecture method of teaching was used in this course. The course was team taught where many technological devices were used to bring about instant learning opportunities. More effective learning is the result from several years of using this method of teaching.
\end{abstract}

Keywords: Learning, Audio, Video, Podcasts, Blogging

\section{INTRODUCTION}

Historically, Microcomputer Applications was a sophomore level course. It was changed to a freshmen level course for all business students. The lecture method was used until the technology consultant volunteered to team teach this course. It has been technology based every since and it relates to the visual freshmen generation that is coming to the university.

Traditional classrooms and $21^{\text {st }}$ Century Classrooms are quite different. Smart boards are now available in the classroom. Each student has access to a computer during scheduled class time. The classroom is also equipped for physically challenged students. The professor's station is equipped with two screens. The first screen displays information for the students. The second screen displays each student's monitor. The teacher may send in-class messages to students regarding the assigned work. In addition, the professor might suggest closing Facebook, MySpace, email and any non-related topic being surfed on the internet and ask the student to focus on the current assignment.

Mobility is brought into the classroom with the many gadgets that students have for daily communication. In the classroom, when it is appropriate, smart boards with screens, the use of internet along with student gadgets allow teachers to bring the world to the

Volume X, No. 1, 2009 classroom. The technology is easy and simple to install and use and has a high level of security.

\section{IMPORTANCE}

Using audio and video prepare students to be a part of a mobile workforce. According to Edwards [2], and Sweeney [9] people's time constraints should be re-engineered to produce, deliver and encourage formal and informal learning. How to incorporate mobile learning with audio and video is the issue not whether it should be used. On-demand training and distance education can also use the same technologies. It is a challenge but it keeps the students and employees informed in a timely manner.

For students who are awaiting the opportunities in the workforce, creativity, hands- on experience, and online and shared information and resources are being experienced.

\section{LITERATURE REVIEW}

A huge amount of materials is available on video cassettes and headphone usage which are now obsolete when compared to devices we have access to today. However, a small number of published materials are available on the use of audio and video with the use of podcasts, mps players, blogs, etc. A lot of energy and discussion is expended on improving faculty teaching and student learning using these devices.

Differences between web-based learning and traditional classroom teaching were studied by Garcia-Rutz [5] and Eskicioglu[3]. Emphases were placed on blended learning methods for teaching management information systems because it allowed for learning anywhere and anytime. Torres [10] likes the idea that communication technology and greater bandwidth allows a college education to be only a mouse click away. McKinney [8] stated that communicating with podcasting scored significantly higher than the lecture condition. Evans [4] found that "Students believe that podcasts are more effective than their own notes in helping them to learn. They also indicated that they are more 
receptive to the learning material in the form of a podcast than a traditional lecture or textbook. The study suggests that the use of podcasts as a revision tool has clear benefits as perceived by undergraduate students in terms of the time they take to revise and how much they feel they can learn. Coupled with the advantages of flexibility in when, where and how it is used, podcasting appears to have significant potential as an innovative learning tool for adult learners in Higher Education." This is also true when blogs are used as a ways to help prepare for class. Materials may be prepared by students on the "fly" with Blackberry, PDA, cell phone, mP3 player, tablet pc, etc.

Dalsgaard [1] argues that the roles of professors and students change. The professor used less time presenting materials which allowed students more time to use their devices to learn the material. Lang [7] reports that the traditional lecture remains the dominant mode of teaching in many college classrooms today, but argues that lecturing should not constitute the sole teaching technique in a course. Materials need to be prepared ahead of time so that students will have materials subsequent to class meetings.

Business faculty tends to be pragmatic in their acceptance of technology and place more emphasis on the compatibility of the technology with their duties says Gibson [6]. Others areas such as music, French and math use videos for learning and teaching.

\section{METHODOLOGY}

Initially, one professor was using the lecture method to teach Microcomputer Applications which is a core course in the School of Business. The professor taught chapter material using the traditional lecture and gave four major examinations. Information on the four examinations was not gathered from student enrolled in Microcomputer Applications for assessment. This method continued for years where the basic Learning Goal for the course is to produce and utilize quantitative, qualitative, and computerbased information for decision making. Two objectives were derived from this learning goal and they are 1) to create and maintain a database, describe how to develop query, and create forms and reports, and 2) to build a worksheet, analyze worksheet value changes, create multiple worksheets, and prepare charts from spreadsheet data.
The University provides a Center for Excellence in Teaching and Learning, CETL. One expert professor from the Center or Excellence in Teaching and Learning come to observe the classes. Professors decided to team up and observed more classes and discuss current learning and teaching methods. Also, professors read about different methods in the literature that stated in some classes videos are used to teach teachers how to teach elementary, middle, and high school teachers. After reviewing the literature to see what other methods were being employed in similar courses, the professors conducted several more observations and meetings concerning the classes. Professors decided that a change was needed and meetings and observations continued while the two professors started to work on revising the course to include methods other than lectures. Then the professors incorporate some of these new methods in this course.

Since methodology had to change, the professors felt it was time to use audio and video to teach college freshmen students so maximum learning would take place. This exposure might add value to the college student experiences. Activities were outlines for each day of the week to acclimate freshmen to college life. Saturday and Sunday students read the new topic material in the textbook. Monday everyone met for in-class discussion to guide the students based on what they read. Students completed the blog on Tuesday, and Wednesday during class students completed the podcast. Thursday students submitted an online concept assessment, and Friday the tutorial was due. The schedule was repeated for the next week on a new topic.

The goal and objectives had already been established for the course. To reach the course objectives, various activities were designed and developed as new technologies were added to the course. Therefore, the new methods were applied to in-class and out-of-class activities which were now used in Microcomputer Applications. Professors selected new methods including U-Tube snippits for class viewing. Brief audio reviews of chapters prior to reading were available, short videos of material that were assumed to be prior knowledge were shown, and audio discussion boards were used. The syllabus was placed in Blackboard where students could review information on a daily basis. The syllabus included objectives used across the board with all professors of eight - ten sections each semester. A calendar was organized with daily assignments including chapter, due date and time, and the activity. Since it is a skills course students were then allowed 
to use appropriate technological devices to accomplish weekly tasks.

In Table 1, in-class and out-of-class activities designed and developed by professors are listed.

Table 1

\begin{tabular}{|l|l|}
\hline Major Exam (concepts) & 30 Percent \\
\hline $\begin{array}{l}\text { Quizzes (on-line } \\
\text { assessments) }\end{array}$ & 30 Percent \\
\hline $\begin{array}{l}\text { Homework (blogs, } \\
\text { Chapter Projects. } \\
\text { Tutorials) }\end{array}$ & 20 Percent \\
\hline $\begin{array}{l}\text { In class (podcasts, } \\
\text { Assignments) }\end{array}$ & 20 Percent \\
\hline
\end{tabular}

With changes in teaching and learning methods, assessments are completed for activities and scores assigned to each of the four categories. Major exams and test are administered every three weeks. Examinations consisted of 60 concept items where students had one hour to complete the examination. However, quizzes were given weekly. Students had 12 hours on Thursday to go online and complete the online concept assessment. For homework, students had a longer period of time to complete assignments. A blog had to be completed within 24 hours on Tuesday. Students wrote a blog after reading each chapter without the use of the textbook. Likewise, the time for online tutorial was 24 hours long and due on Friday. Chapter projects were completed over a seven-day period during the same week that blogs, podcast, etc were due. Chapter projects were completed and saved on flash drives each week. Inclass activities were in a structures classroom setting. Because headsets were issued, podcasts were completed during class time on Wednesday. Students used headsets for daily communication and really related to using the headsets in class to complete the podcast each week. The remainder of the class time was used for other activities. Most all activities were assessable online weekly where students had the opportunity to complete practice exams before completing the online assessments.

Students had the capability to upload and download materials at will in and out of class using $\mathrm{mP3}$ players, iPods, and smart phones. Blending the various methods together keeps good studentprofessor interaction, improve professors teaching methods, and more importantly improve student learning.

\section{RESULTS}

Based on the literature review and data collected, it is obvious that video and audio can be effective in learning materials in skill courses. Initially, the professor was lecturing and using only major examinations four times during the semester without score comparison of what students were doing in and out of class. However, an average score of 68 was calculated for all of the major exams using the lecture method. After observing the class and reading materials on methodologies of learning the course was revised. Students began to use technological devices to completed blogs, podcasts, online assessments and tutorials during the week for each new topic. Blogs and podcasts were completed on a topic called "what you learned" with the purpose to improve scores on assessments. Recording of blogs gave students more interaction with the content of each chapter. Students seemed to have been affected positively when they used these devices because they saw them as useful and recognized that the technology is easy to use and supports academic needs. See Table 2 for changes in scores over the years.

Table 2

\begin{tabular}{|l|c|c|c|c|}
\hline \multicolumn{1}{|c|}{ Activity } & $\begin{array}{c}\text { Average } \\
\text { Score } \\
\text { Lecture } \\
\text { Method } \\
2006\end{array}$ & $\begin{array}{c}\text { Average } \\
\text { Score } \\
2007\end{array}$ & $\begin{array}{c}\text { Average } \\
\text { Score } \\
2008\end{array}$ & $\begin{array}{c}\text { Average } \\
\text { Score } \\
2009\end{array}$ \\
\hline $\begin{array}{l}\text { Major } \\
\text { Exam } \\
\text { (concepts) }\end{array}$ & 68 & 70 & 72 & 72 \\
\hline $\begin{array}{l}\text { Quizzes } \\
\text { (on-line } \\
\text { assessmen } \\
\text { ts) }\end{array}$ & $\begin{array}{c}\text { Not } \\
\text { Used }\end{array}$ & 80 & 80 & 82 \\
\hline $\begin{array}{l}\text { Homewor } \\
\text { k (blogs, } \\
\text { Chapter } \\
\text { Projects. } \\
\text { Tutorials) }\end{array}$ & $\begin{array}{c}\text { Not } \\
\text { Used }\end{array}$ & 63 & 75 & 74 \\
\hline $\begin{array}{l}\text { In class } \\
\text { (podcasts, } \\
\text { Assignme } \\
\text { nts) }\end{array}$ & Not & 61 & 71 & 73 \\
\hline
\end{tabular}

Since starting to use technological devices, more data were collected for the course. Beginning in 2007, three additional electronic device activity categories were added - quizzes, homework, and in class. That year the professors assumed the social use of devices for texting and downloading music would automatically transfer to academic activities. The professors assumed later that social use did not 
transfer to the classroom as reflected in an average score of 63 for homework (blogs) and 61 for in-class (podcasts). Evidently, students were accustomed to some form of online quizzes and that adjustment to devices was not as drastic as shown with a score of 80 .

The next year, 2008, more in class emphasis was placed on "how to" use the technological devices and more one-on-one interaction with professors and students occurred. The scores increased in two areas. Homework increase 12 points and in-class 10 points. The quizzes remained constant at 80 as the previous year. During 2009, professors continued using "how to" with all sections of the course. Scores continued to increase slightly with the exception of homework which dropped 1 point. Overall there was a slight increase in the major exam average.

\section{CONCLUSION}

Over the years, changes were made to a core course in business called Microcomputer Applications. Opportunities for oral communication with blogs and podcasts allowed students to learn while reinforcing skills and concepts. Integration of technology and communication devices is a true indicator of effectiveness in improving student learning. These methods of learning kept students more actively engaged while learning. Listening to what other students learned help students prepare and complete podcasts and other assignments. Overall, this experience provided access to information 24/7, facilitated collection and processing of class activities, created an interactive classroom, and provided immediate feedback to students.

Because of the small group of students, the study in no way suggests that $21^{\text {st }}$ century learning methodologies should replace the classroom professor. It does indicate that repeating the same or similar materials in different forms help students to learn materials and earn higher scores on activities.

\section{REFERENCES}

1. Dalsgaard, Christian and Mikkel Godsk. (2007). Transforming Traditional Lectures into Problem-Based Blended Learning: Challenges and Experiences. Open Learning, 22(2), 29-42.
2. Edwards, Ron. (2005). Knowledge Sharing for the Mobile Workforce. Chief Learning Officer, 4(5), 48-53.

3. Eskicioglu, Ahmet and Danny Kopec. (2003). The Ideal Multimedia-Enabled Classroom: Perspectives from Psychology, Education, and Information Science. Journal of Educational Multimedia and Hypermedia, 12(2), 199-221.

4. Evans, Chris. (2008). The Effectiveness of m-learning in the Form of Podcast Revision Lectures in Higher Education, Computers in Education, 50(2), 491-498.

5. Garcia-Ruiz, Maria Elena. (2006). Teaching Management Information Systems with Blended Learning Methods: an experience with WebCT. International Conference IADIS.

6. Gibson, Shannan G. (2008). Technology Acceptance in an Academic Context: Faculty Acceptance of Online Education, Journal of Education for Business, 83 (6), 355-359.

7. Lang, James M. (2006). Beyond Lecturing. The Chronicle of Higher Education, 53(6), C.1.

8. McKinney, Dani, Jennifer Dyck, Elise Luber. (2009). ITunes University and the Classroom: Can Podcasts Replace professors? Computers and Education, 52(3), 617-623.

9. Sweeney, Paul. (2007). Web-Based Learning gains More Converts, Financial Executive, 23(4), 18-21.

10. Torres, Nichole L. (2008). School's InOnline, Entrepreneur, 36(10), 136-137. 